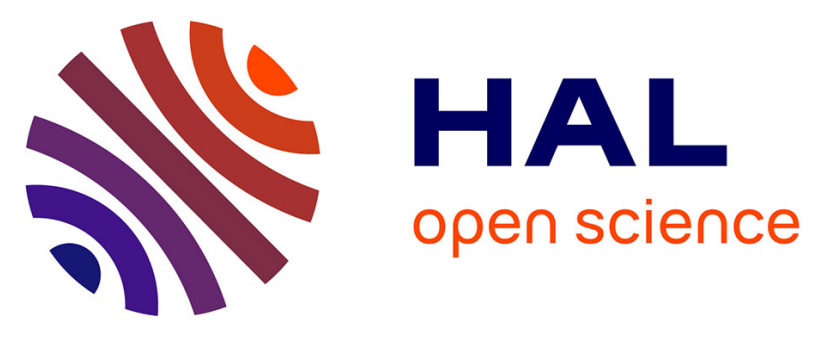

\title{
Evidence of clinical and genetic heterogeneity in autosomal dominant congenital cerulean cataracts
}

Latifa Hilal, Emeline Nandrot, Mohamed Belmekki, Siham El Bacha, Mohamed Chefchaouni, Bouchra Benazzouz, Yassir Hajaji, Olivier Gribouval, Jean-Louis Dufier, Marc Abitbol, et al.

\section{To cite this version:}

Latifa Hilal, Emeline Nandrot, Mohamed Belmekki, Siham El Bacha, Mohamed Chefchaouni, et al.. Evidence of clinical and genetic heterogeneity in autosomal dominant congenital cerulean cataracts.

Ophthalmic Genetics, 2002. hal-03086816

\section{HAL Id: hal-03086816 https://hal.science/hal-03086816}

Submitted on 17 Nov 2021

HAL is a multi-disciplinary open access archive for the deposit and dissemination of scientific research documents, whether they are published or not. The documents may come from teaching and research institutions in France or abroad, or from public or private research centers.
L'archive ouverte pluridisciplinaire HAL, est destinée au dépôt et à la diffusion de documents scientifiques de niveau recherche, publiés ou non, émanant des établissements d'enseignement et de recherche français ou étrangers, des laboratoires publics ou privés. 


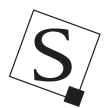

Ophthalmic Genetics I38I-68Io/02/ US\$ I6.00

Ophthalmic Genetics - 2002, Vol. 22

No.3, pp.

(C) Swets \& Zeitlinger 2002

Accepted 20 June 2002

\section{Evidence of clinical and genetic heterogeneity in autosomal dominant congenital cerulean cataracts}

\author{
Latifa Hilal ${ }^{1}$ \\ Emeline Nandrot ${ }^{2}$ \\ Mohamed Belmekki ${ }^{3}$ \\ Siham EI Bacha ${ }^{1}$ \\ Mohamed Chefchaouni ${ }^{3}$ \\ Bouchra Benazzouz ${ }^{1}$ \\ Yassir Hajaji ${ }^{1}$ \\ Olivier Gribouval ${ }^{4}$ \\ Jean-Louis Dufier ${ }^{2}$ \\ Marc Abitbol ${ }^{2}$ \\ Amina Berraho ${ }^{3}$
}

\begin{abstract}
${ }^{1}$ Laboratoire de Génétique et Biologie Moléculaire de la Faculté des Sciences, Université IBN Tofail, Kénitra, and ${ }^{3}$ Département d'Oto-Neuro-Ophtalmologie, Service d'Ophtalmologie B, Hôpital des Spécialités, Rabat, Morocco ${ }^{2}$ Centre de Recherches Thérapeutiques en Ophtalmologie de la Faculté de Médecine Necker, EA n²502 du Ministère de la Recherche et de I'Enseignement Supérieur, Université René Descartes, Paris, and ${ }^{4}$ Unité INSERM 423, CHU Necker-Enfants Malades, Paris, France
\end{abstract}

\begin{abstract}
Autosomal dominant cerulean cataracts (ADCC) have previously been mapped to two loci: one on chromosome I7q24 and the other on chromosome 22qI I.2-qI 2.2, which includes the $\beta$-B2 crystallin $(\mathrm{CRYBB} 2)$ candidate gene. Using polymorphic markers in these regions (Di7S802, Di7S836, Di7 $\mathrm{S}_{1} 806$ and CRYBB2, D22S258) for linkage analysis, we excluded these loci in a large Moroccan family presenting with an unusual form of ADCC with early onset of lens opacities and rapid evolution. This finding confirms the clinical and genetic heterogeneity of autosomal dominant congenital cerulean cataracts.
\end{abstract}

Key words Congenital cerulean cataract; clinical heterogeneity; genetic heterogeneity
Correspondence and reprint

requests to:

Marc Abitbol

Centre de Recherches

Thérapeutiques en Ophtalmologie

Faculté de Médecine Necker-Enfant

Malades

I56 Rue de Vaugirard

75015 Paris cedex

France

Tel: oo 33 I 406 I 56 56/56 57

E-mail: abitbol@necker.fr 


\section{Acknowledgements:}

We are grateful to the family members for their participation in this study and warmly thank all members of the medical staff of the Department of Ophthalmology B (Hôpital des Spécialités de Rabat, Morocco). This work was supported by 'Programme d'appui à la recherche scientifique' (Pars Médecine $\left.\mathrm{N}^{\circ} \mathrm{I} 5 \mathrm{I}\right)$ and a research grant from INSERM (Programme PROGRES), a grant to the CERTO Laboratory from RETINA France, and a grant from the Faculté de Médecine Necker and Université René Descartes. Emeline Nandrot was supported by a grant from Fondation pour la Recherche Médicale.
Introduction Cataracts are the most common treatable cause of visual disability in childhood, ${ }^{\mathrm{I}-\mathrm{I} 3}$ with an incidence of $\mathrm{I}-6$ per I0,000 live births. An estimated 200,000 children worldwide are blinded by bilateral cataracts and 20,000-40,000 children are born with developmental cataracts each year. In the developed countries of Europe and Northern America, national surveillance or cross-sectional studies indicate a prevalence of I-4 cases per Io,ooo children. In other geographic areas, the prevalence may be higher, approximately 6-7 cases per I0,000 children. Congenital cataracts account for I0-40\% of the registered cases of blindness in children in developed countries. In nearly one third of these cases, congenital cataracts are familial. Autosomal dominant segregation of hereditary cataracts is the most frequent mode of transmission. ${ }^{\text {I }}{ }^{-16}$ Hereditary congenital and early onset cataracts are clinically highly heterogeneous and show considerable inter- and intrafamilial variability. ${ }^{14-16}$ To date, more than ${ }_{5} 5$ independent loci have been identified for autosomal dominant congenital cataracts on different chromosomes. These include five genes encoding crystallins (CRYAA [MIM I23580], CRYBA3/AI [MIM I236Io], CRYBB2 [MIM I23620], CRYGC [MIM I23680], and CRYGD [MIM I23690]), two genes encoding gap-junction channel proteins (GJA3 [MIM I2I05I] and GJA8 [MIM 600897]), one gene encoding the regulatory factor PITX $_{3}$ [MIM 602669], and one gene encoding beadedfilament structural protein-2 (BFSP2 [MIM 6032I2]). ${ }^{17-19}$ Cataracts have been shown to be genetically heterogeneous, because more than one gene can cause the same phenotype. ${ }^{\mathrm{I}, 19}$ Cerulean cataracts (ADCC), first described by Vogt in $\mathrm{I} 92 \mathrm{I},{ }^{20}$ are characterized by early onset, progressive development of bilateral lens opacities, and complete penetrance. Affected newborns appear asymptomatic until the age of I $8-24$ months. At that time, they can be clinically diagnosed by slit-lamp examination by means of the appearance of tiny blue or white opacities that first develop in the superficial layers of the fetal lens nucleus. Armitage et al. ${ }^{21}$ suggested that cerulean cataracts should be classified as developmental cataracts rather than as congenital cataracts. The opacities spread throughout the adult lens nucleus and cortex and form concentric layers with radially oriented central lesions. Two loci have been mapped in distinct large families affected by cerulean ADCC: one (CCAI) is localized on chromosome I7q24 between $\mathrm{D}_{17} \mathrm{~S} 802$ and $\mathrm{D}_{17} \mathrm{~S} 836,{ }^{21}$ while the other (CCA2) has been mapped to chromosome 22qII.2-qI2.2, which also carries the CRYBB2 gene., ${ }^{22}$ Litt et al., ${ }^{23}$ showed that all patients with the CCA2type ADCC carry a chain termination mutation in the CRYBB2 gene.

We excluded these two loci as the cause of a severe form of ADCC, characterized by the appearance of blue and white opacities that could be detected at birth, in all affected patients in a large affected Moroccan family.

\section{Patients and methods}

CLINICAL Findings/FAmily members A total of 43 individuals from four generations were identified in a Moroccan family. Slit-lamp and ocular fundus examinations were used to diagnose i9 patients with 

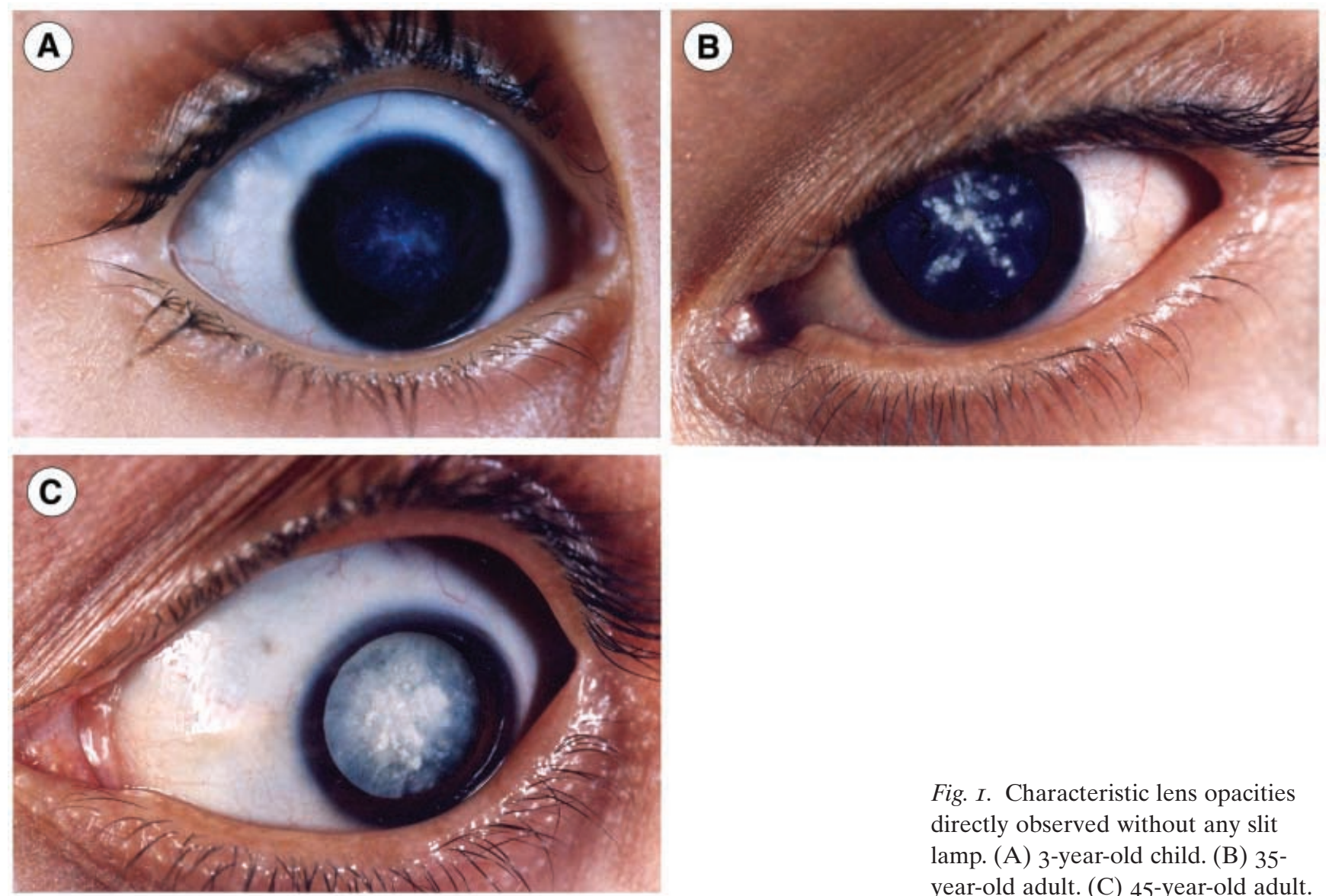

Fig. I. Characteristic lens opacities directly observed without any slit lamp. (A) 3-year-old child. (B) 35year-old adult. (C) 45-year-old adult.

cerulean cataracts belonging to this family (Fig. I). Each generation included at least two affected patients and contained affected males and females (Fig. 2). The mode of transmission of this unusually severe form of cerulean cataracts is indeed autosomal dominant. There was no history of significant and possibly related systemic disease in any member of this family. Variability of expression of the trait could be observed between individuals of the same age regardless of their gender or generation. Similarly, the evolution of this bilateral hereditary disease varied from one patient to another and between the eyes of individual patients. It is noteworthy that the lens opacities could be observed in all affected patients at birth by direct visual observation without the need for slit-lamp or ocular fundus examinations. The diagnosis was consistently established at birth by unaffected family members. Some patients had extremely decreased or nondetectable visual acuity at birth, whereas others retained very low but detectable vision. Nystagmus was not unusual during the first month(s) of life in some of the severely affected patients. The first examination was performed by an ophthalmologist around the seventh post-natal month in the best-case scenario. For economic reasons, surgery was performed on only 20 eyes at a mean age of 28 years (range: I- 82 years; median 26 , mode 26). Some severely affected children underwent lens extraction before the age of 5 years. Most members of this family did not undergo lens extraction in their infancy due to economic restraints. It 


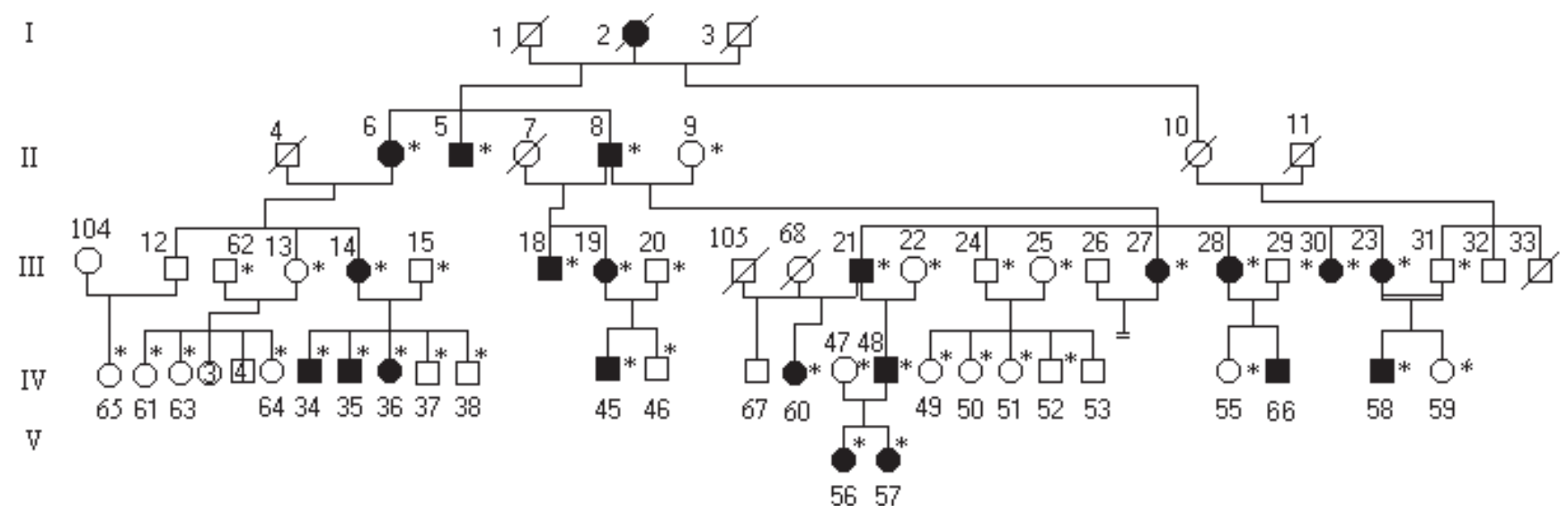

Fig. 2. Pedigree of the studied multigeneration cerulean cataract family. Squares and circles symbolize males and females, respectively. Solid symbols indicate affected individuals, open symbols unaffected family members. Asterisks indicate studied members. appeared that the progression of cerulean cataract in this family followed a faster time course than that reported in other families. . $7,18,22,23$ Nevertheless, in some patients who had been regularly examined, it was found that the progression of the cerulean opacities was similar to that described by Armitage et al., ${ }^{21}$ Kramer et al. ${ }^{22}$ and Vogt $^{20}$ in terms of layers and location of their lens opacities. The phenotype described here differs from that reported in other families with ADCC in that the opacities appear at birth and the progression of the cataract is faster.

GENOTYPING Blood samples were collected from 43 individuals who gave informed consent and DNA was prepared according to standard methods. To analyze each microsatellite marker, oligonucleotide primer sequences were taken from a genome database (http://www.gdb.org). The microsatellites were amplified from leukocyte DNA in a PTC225 (MJ Research, Boston, MA, USA) thermocycler. Each PCR was performed in a final volume of $20 \mu$ l containing 50 ng genomic DNA, $0.25 \mu \mathrm{M}$ of each primer, I.5-2 $\mathrm{mM} \mathrm{MgCl}_{2}, \mathrm{IOO} \mu \mathrm{M}$ of each dNTP, and $0.4 \mathrm{U}$ Taq polymerase (Promega, Paris, France). After a 5-min incubation at $94^{\circ} \mathrm{C}$, the samples underwent 30 PCR cycles (denaturation at $94^{\circ} \mathrm{C}$ for $30 \mathrm{~s}$, annealing at $55^{\circ} \mathrm{C}$ for $40 \mathrm{~s}$, extension at $72^{\circ} \mathrm{C}$ for I min, and a final extension step for $5 \mathrm{~min}$ ). The PCR products were separated by electrophoresis on standard denaturing polyacrylamide gels $(6 \%)$ and transferred to positively charged nylon membranes $\left(\mathrm{Pall}{ }^{\mathrm{TM}}\right)$. The membranes were hybridized for $3 \mathrm{~h}$ or overnight at $42^{\circ} \mathrm{C}$ with a primer that had been labelled with $[\alpha-32 \mathrm{P}]-\mathrm{dCTP}$ using terminal transferase (Boehringer, Mannheim, Germany). After autoradiography, the genotypes were determined in a double-blind manner by two independent individuals who did not know the identities of the patients.

LiNkAgE ANALYSis Two-point disease-to-marker linkage analysis was conducted using MLINK from the FASTLINK (version 3.oP) software package. ${ }^{24,25}$ The mode of inheritance was considered to be autosomal dominant with full penetrance. Gene frequency was set at $\mathrm{I} / 20,000$. Since the allelic frequencies of the polymorphic markers were unknown for the entire Moroccan population, they were considered 


\begin{tabular}{|c|c|c|c|c|c|c|c|c|}
\hline \multirow[t]{2}{*}{ Marker } & \multicolumn{7}{|c|}{$L O D$ scores at $\theta=o$} & \multirow{2}{*}{$\begin{array}{l}\text { Exclusion } \\
(Z=-2)\end{array}$} \\
\hline & $O . O$ & $O . O I$ & 0.05 & $O . I$ & 0.2 & 0.3 & 0.4 & \\
\hline $\mathrm{D}_{17} \mathrm{~S} 802$ & $-\infty$ & -20.76 & -II.I4 & -7.15 & -3.46 & $-\mathrm{I} .6 \mathrm{I}$ & -0.55 & 0.28 \\
\hline $\mathrm{D}_{17} \mathrm{~S} 836$ & $-\infty$ & - I3.39 & -7.24 & -4.70 & -2.36 & -I.I6 & -0.45 & 0.23 \\
\hline Di7Si806 & $-\infty$ & $-2 \mathrm{I} \cdot 5^{8}$ & $-\mathrm{II} .78$ & -7.66 & -3.78 & $-\mathrm{I} .80$ & -0.64 & 0.29 \\
\hline $\mathrm{CRYBB}_{2}$ & $-\infty$ & $-\mathrm{I} 2.5^{8}$ & -5.88 & -3.23 & $-\mathrm{I} . \mathrm{OO}$ & -0.I0 & 0.17 & 0.15 \\
\hline $\mathrm{D}_{22} \mathrm{~S}_{258}$ & $-\infty$ & -8.12 & $-3 \cdot 39$ & $-\mathrm{I} .55$ & -0.10 & 0.35 & 0.33 & 0.08 \\
\hline
\end{tabular}

equal. The genetic distances were taken from the Marshfield database (http://research.marshfieldclinic.org).

Results We identified a large Moroccan family affected with ADCC. This family differs from those described previously because the distinct bluish and white opacities were obvious at birth and because the cataracts progressed more rapidly, leading to complete blindness that required bilateral extraction of the lens. We determined the genotype of all of the individuals in this large family using the following polymorphic markers: Di7S802, Di7SS836, Di7Si806, D22S258, and CRYBB2. These polymorphic markers yield the highest LOD scores corresponding to the known loci of ADCC. Three polymorphic markers were used to test for linkage with the CCAI locus: Di7S802, Di7SS836, and Di7Si806. Two polymorphic markers were used to test for linkage with the CCA2 locus: one marker was extragenic but located near the CRYBB2 gene and one marker, $\mathrm{D}_{22} \mathrm{~S}_{25}$, was intragenic located within the CRYBB2 gene. The results of our two-point linkage analysis are shown in Table I. There was no evidence for co-transmission of any particular allele with the disease.

The existence of recombination fractions with a LOD score of -2.00 (Table I) allowed us to exclude a minimal region of more than 20 centiMorgan $(\mathrm{cM})$ on either side of each of the markers used to search for linkage with the I7q24 locus and more than $15 \mathrm{cM}$ on either side of the intragenic candidate gene CRYBB2. The two-point LOD score analysis was negative for all markers at $\theta=0$ and provided evidence for the exclusion of the tested candidate loci. Thus, our study demonstrates genetic heterogeneity for the autosomal congenital cerulean cataracts and suggests that a third locus is involved in the appearance of this phenotype.

Discussion The carefully determined phenotype in all affected members of this large Moroccan family indeed corresponds to that of autosomal dominant congenital cerulean cataracts. The discrete, pinhead-shaped, blue-white opacities are detectable at birth and are apparent in the first months of life. They are distributed throughout the lens, becoming more numerous in the cortex where they form large cuneiform (wedge-like) clumps in the midperiphery. Within the reported pedigree, the opacities are consistent in their distribution, but variable in their severity. The only, albeit important, difference with the
TABLE I. Two-point LOD scores of Morrocan cerulean ADCC, with markers at the candidate loci on chromosomes I7q24 and 22qII.2-qI2.2. 
clinical description of congenital cerulean cataracts first described by Vogt is the speed of progression of the cataracts in the present family (we carefully monitored the progression of lens opacification). The diagnosis established for this family cannot be confused with congenital coralliform cataracts, congenital lamellar cataracts, or congenital pulverulent cataracts. All other possible clinical aspects of congenital cataracts were carefully assessed and eliminated on the basis of internationally accepted criteria for the diagnosis of congenital cataracts. ${ }^{15,17,18}$

With very few exceptions, it is impossible to deduce the underlying molecular lesion causing inherited congenital cataracts from clinical observation and alternatively to predict the resulting phenotype from the characterized mutation. Clinically similar phenotypes of autosomal dominant congenital cataracts map to different regions of the genome and different phenotypes map to the same locus. At least three different pedigrees affected by blue dot (cerulean cataract) have been mapped to different chromosomes. ${ }^{172-23}$ This report strengthens the hypothesis of the existence of at least one more locus for ADCC. Different pedigrees of dominantly inherited polar cataracts have been linked to the haptoglobin locus on $\mathrm{I} 6 \mathrm{q},{ }^{26}$ to a locus on Ip $36,{ }^{27}$ and to a third locus on IIq22-22.3. ${ }^{28}$ For the British family's cataracts linked to the IIq22 locus, ${ }^{28}$ a frameshift mutation has been identified in the coding sequence of the gene encoding the $\alpha$-B crystallin protein (CRYAB). The Coppock-like cataract, which is a nuclear type of congenital cataract, corresponds to two different loci: one mapped to chromosome $2 \mathrm{q} 33-35^{29}$ and one assigned for another pedigree to chromosome 22qII.2. ${ }^{30}$ The mutation causing the Coppock-like cataract linked to chromosome $2 \mathrm{q} 33-35^{30}$ has been identified as an A-to-C transversion in exon 2 of the $\gamma$-C crystallin (CRYGC) gene. ${ }^{31}$ This mutation changes the amino acid threonine in position 55 to a proline $\left(\mathrm{T}_{5} \mathrm{P}\right) .{ }^{3 \mathrm{I}}$ The mutation causing the Coppock-like congenital cataract in the pedigree linked to the chromosome $22 \mathrm{qII} .2$ has been also described.$^{30}$ It is a stop codon in exon 6 of the gene encoding the $\beta$-B2 crystallin (CRYBB2). More recently, a mutation introducing a stop codon in the coding sequence of the gene encoding the $\gamma$-D crystallin (CRYGD) was identified as the molecular cause of an autosomal dominant congenital nuclear cataract..$^{32}$ Two different forms of congenital cataracts, the posterior polar cataract ${ }^{26}$ and the Volkman cataract, ${ }^{33}$ both map to what may prove to be the same locus on chromosome Ip36.

Conversely, different mutations of the same gene can cause diverse phenotypes. Mutations in the $\alpha$-crystallin gene are known to be cataractogenic. A splice-site mutation ${ }^{34}$ is thought to be responsible for the sutural (lamellar) opacities observed in a family mapped to I7q and a missense mutation in the $\alpha$-A crystallin gene has been identified as the cause of the congenital zonular nuclear cataract affecting another family. ${ }^{35}$ The $\beta-\mathrm{B}_{2}$ crystallin is the only member of the $\beta$-crystallin gene cluster on $22 \mathrm{q}$ to be highly transcribed in the lens. Different mutations in this gene are now known to result in the development of cerulean cataracts $^{23}$ and the Coppock-like cataract. ${ }^{30}$ Different mutations of the $\gamma$-C crystallin gene can also result in a Coppock-like congenital 
cataract $^{31}$ or an autosomal dominant lamellar cataract..$^{32}$ Several distinct mutations of the CRYGD gene can trigger the emergence of different clinical presentations of congenitally or noncongenitally inherited cataracts. A single base alteration, resulting in an Arg $\rightarrow$ Cys (RI4C) substitution in CRYGD, was shown to cause pulverulent cataract with juvenile onset and progressive evolution, segregating as an autosomal dominant trait in a three-generation pedigree. ${ }^{36}$ Mutational analysis of the CRYG gene cluster localized the mutation responsible for aculeiform cataracts in exon 2 of CRYGD. ${ }^{3 \mathrm{I}}$ This mutation occurs in a highly conserved amino acid and may be associated with incorrectly folded CRYGD. Other well-defined mutations of the CRYGD gene can cause either a lamellar or a nuclear form of congenital cataract. ${ }^{32}$ A missense mutation in the human MIP gene encoding the major intrinsic protein of the lens underlies autosomal dominant 'polymorphic', i.e. progressive, lamellar opacification of the lens associated with anterior and posterior polar cataracts. ${ }^{37}$ Another missense mutation in the MIP gene triggers a nonprogressive opacification of the lens and exclusively involves the perinuclear lamella of the lens, not the nucleus or the poles of the lens. ${ }^{38}$ These are striking examples of allelic heterogeneity.

Before we can identify the genetic alteration causing the cerulean ADCC in the present Moroccan family, we have to obtain a significant LOD score using linkage analysis with polymorphic markers. As different mutations in the gene encoding a given crystallin can trigger the appearance of distinct phenotypes of cataracts, the most appropriate strategy for identifying a positive linkage is to perform a linkage analysis with markers flanking the genes encoding other crystallins in which known mutations cause other types of congenital cataracts. We will continue our linkage study with all polymorphic markers flanking other genes encoding proteins different from crystallins, such as junctional proteins, or with markers corresponding to mapped loci for other types of congenital cataracts, including the loci inferred by synteny from the mapping studies performed in spontaneous mice models of inherited cataracts or in inherited cataracts occurring in mice after mutagenization. ${ }^{39}$ If this widened candidate approach also fails to provide a positive linkage, we will screen the entire genome for a new locus for inherited congenital cataracts.

It is important to emphasize that the phenotype of the family studied here is not identical to those described for the ACCI and ACC2 loci. This further supports genetic heterogeneity. The variability of the phenotype of different affected individuals in this family, in which the cataracts are transmitted as a monogenic autosomal dominant trait, suggests the action or contribution of modifier genes. Piatigorsky's group ${ }^{40}$ showed that transcription factors, such as PAX6, can transactivate crystallin gene expression and the expression of other genes that are normally transcribed in the lens. An interindividual variability in the sequence of the promoter region of the gene whose alteration causes the severe form of cerulean ADCC observed in this family may change the affinity of the transactivating factors to the promoter region in each member of the family. This differential transactivation may result in different levels of transcription of the same gene and in dif- 
ferent concentrations of the encoded target protein in the lenses of different members of the same family.

Another aspect of our clinical study of the present family has revealed that the economic situations in developing countries hinder the extraction of severe congenital cataracts early in infancy, leading to substantial vision loss. Early detection of inherited congenital cataracts by pediatricians, ophthalmologists, and geneticists should be urgently undertaken in developing countries to decrease the public health burden caused by these preventable causes of blindness and should be one of the World Health Organization's highest priorities.

\section{References}

I Tsukahara S, Sasamoto M, Watanabe I, Phillips CI. Diagnostic survey at Yamanashi School for Blind: importance of heredity. Jpn J Ophthalmol. I985;29:3 I5$32 \mathrm{I}$.

2 Angra SK, Rao P, Panda A, Grewal MS. Genetic appraisal of congenital cataract. Indian J Ophthalmol. I987; 35:226-232.

3 Phillips CI, Levy AM, Newton M, Stokoe NL. Blindness in schoolchildren: importance of heredity, congenital cataract, and prematurity. Br J Ophthalmol. I987; 7I:575-584.

$4 \mathrm{Hu} \mathrm{DN}$. Prevalence and mode of inheritance of major genetic eye diseases in China. J Med Genet. I987;24:584-588.

5 James L. M maps of birth defects occurrence in the US, birth defects monitoring. Teratology. I993;48: 55 I -646.

6 Rosenberg T. Congenital and hereditary visual impairment in Greenland. Arctic Med Res. I994;53: 9I-96.

7 Eckstein M, Vijayalakshmi P, Killedar M, Gilbert C, Foster A. Aetiology of childhood cataract in south India. Br J Ophthalmol. 1996; 80:628-632.

8 Foster A, Gilbert C, Rahi J. Epidemiology of cataract in childhood: a global perspective. $J$ Cataract Refract Surg. 1997;23: 60I-604.

9 Dandona L, Williams JD, Williams BC, Rao GN. Population based assessment of childhood blindness in
Southern India. Arch Ophthalmol. I998; I I6:545-546.

Io Bermejo E, Martinez-Frias ML. Congenital eye malformations: clinical-epidemiological analysis of I, I 24,654 consecutive births in Spain. Am J Med Genet. I998;75(5): 497-504.

I I Rahi JS, Dezateux C. Congenital and infantile cataract in the United Kingdom: underlying or associated factors. British Congenital Cataract Interest Group. Invest Ophthalmol Vis Sci. 2000;4I:2 I08-2 I I 4.

I2 Rahi JS, Dezateux C. Measuring and interpreting the incidence of congenital ocular anomalies: lessons from a national study of congenital cataract in the UK. Invest Ophthalmol Vis Sci. 200 I;42: I 444-I448.

I3 Rahi JS, Botting B. Ascertainment of children with congenital cataract through the National Congenital Anomaly System in England and Wales. Br J Ophthalmol. 200 I;85: I049-I05I.

I4 Berry V, Singh JR, Singh D. Genetic and segregation analysis of congenital cataract in the Indian population. Clin Genet. I999;56: 389-393.

I5 Merin S. Inherited eye diseases: diagnosis and clinical management. New York: Marcel Dekker, I99I; Ch. 4. Inherited cataracts.

I6 Scott M, Heijtmancik J, Wozencraft L, Reuter L, Parks M, Kaiser-Kupfer M. Autosomal congenital cataract. Ophthalmology. I994; гог:866-87I.

I7 Ionides AC, Francis PJ, Berry V, Mackay DS, Bhattacharya SS, Shiels 
A, Moore AT. Clinical and genetic heterogeneity in autosomal dominant cataract. Br J Ophthalmol. I999;83:802-808.

I8 Francis PJ, Berry V, Bhattacharya SS, Moore AT. The genetics of childhood cataract. J Med Genet. 2000;37:48I-488.

I9 He W, Li S. Congenital cataracts: gene mapping. Hum Genet. 2000; I06:I-I3.

20 Vogt A. Die spezifitat ander borener und erworbener starformer fur die einzelnen linsezonene. Albrecht von Graefe's Arch Klin Exp Ophthalmol. I92 I;I08:2 I9-228.

2 I Armitage MM, Kilvin JD, Ferrell R. A progessive early onset cataract gene maps to human chromosome I7q24. Nat Genet. I995;9:37-40.

22 Kramer P, Yount J, Mitchell T, LaMorticella DM, CarreroValenzuela R, Lovrien E, Maumenee I, Litt M. A second gene for cerulean cataracts maps to the $\beta$ crystallin region on chromosome 22 . Genomics. 1996;35:539-542.

23 Litt M, Carrero-Valenzuela R, LaMorticella DM, Schultz DW, Mitchell TN, Kramer P, Maumenee IH. Autosomal dominant cerulean cataract is associated with a chain termination mutation in the human $\beta$-crystallin gene CRYBB2. Hum Mol Genet. I997;6:665-668.

24 Lathrop GM, Laouel JM. Easy calculations of lod scores and genetic risk on small computers. Am J Hum Genet. 1984;36:460-465.

25 Cottingham Jr RW, Idury RM, Schäffer AA. Faster sequential genetic linkage computation. Am J Hum Genet. I993;53:252-263.

26 Richards J, Maumenee IH, Rowe S, Lovrien EW. Congenital cataract possibly linked to haptoglobin. Cytogenet Cell Genet. 1984;37:570.

27 Ionides AC, Berry V, Mackay DS, Moore AT, Bhattacharya SS, Shiels A. A locus for autosomal dominant posterior polar cataract on chromosome ip. Hum Mol Genet. I997;6:47-5I.

28 Berry V, Francis P, Ashwin Reddy M, Collyer D, Vithana E, MacKay I,
Dawson G, Carey AH, Moore A, Bhattacharya SS, Qinlan R. Alpha-B crystallin (CRYAB) mutation causes dominant congenital polar cataract in humans. Am Genet Hum Genet. 200 I;69: I I 4 I-I I 45.

29 Lubsen N, Renwick J, Tsui L-C, Breitman M, Schoenmackers J. A locus of a human hereditary cataract is closely linked to the gammacrystallin gene family. Proc Natl Acad Sci USA. I987;84:489-494.

30 Gill D, Klose R, Munier FL, McFadden M, Priston M, Billingsley G, Ducrey N, Shorderet DF, Héon E. Genetic heterogeneity of the Coppock-like cataract: a mutation in CRYBB2 on chromosome 22qII.2. Invest Ophthalmol Vis Sci. 2000;4I: I59-I65.

3I Héon E, Priston M, Shorderet DF, Billingsley GD, Girard PO, Lubsen $\mathrm{N}$, Munier FL. The gamma-cristallins and human cataracts: a puzzle made clear. Am J Hum Genet. I999;65: I26I-I 267.

32 Santhiya ST, Shyam Manohar M, Rawlley D, Vijayalakshmi P, Namperumzlsamy P, Gopinath PM, Löster J, Graw J. Novel mutations in the $\gamma$-crystallin genes cause autosomal dominant congenital cataracts. J Med Genet. 2002;39: 352-358.

33 Eiberg H, Lund AM, Warburg M, Rosenberg T. Assignment of congenital cataract Volkmann type (CCV) to chromosome Ip36. Hum Genet. I995;96:33-38.

34 Padma T, Ayyagari R, Murty J, Basti S, Fletcher T, Rao G. Autosomal dominant zonular cataract with sutural opacities localised to chromosome I7qI I-I2. Am J Hum Genet. I995;57:850-855.

35 Litt M, Kramer P, LaMorticella DM, Murphey W, Lovrien EW, Weleber RG. Autosomal dominant congenital cataract associated with a missense mutation in the human alpha crystallin gene CRYAA. Hum Mol Genet. I998;7:47I-474.

36 Stephan DA, Gillanders E, Vandereveen D, Freas-Lutz D, Wistow G, Baxevanis AD, Robbins 
CM, VanAuken A, Quesenberry MI, Bailey-Wilson J, Juo SHH, Trent JM, Smith L, Brownstein MJ. Progressive juvenile-onset punctate cataracts caused by mutation of the gammaDcrystallin gene. Proc Natl Acad Sci USA. I999;96: I008-IoI2.

37 Berry V, Francis P, Kaushal S. Missense mutations in the human MIP gene, encoding the major intrinsic protein of the lens underlie autosomal dominant 'polymorphic' and lamellar cataracts on I2q. Nat Genet. 2000;25:15-I7.
38 Francis P, Berry V, Bhattacharya S, Moore A. Congenital progressive polymorphic cataract caused by a mutation in the major intrinsic protein of the lens, MIP (AQPo). $\mathrm{Br}$ J Ophthalmol. 2000;84:I376-I379.

39 Graw G. Cataract mutations and lens development. Prog Retinal Eye Res. I999; I8:235-267.

40 Duncan MK, Haynes $2^{\text {nd }}$ JI, Cvekl A, Piatigorsky J. Dual roles for Pax6: a transcriptional repressor of lens fiber cell-specific beta-crystalln genes. Mol Cell Biol. I998; 18:5579. 